\title{
EKSTRAKSI DAN STRIPPING URANIUM HASIL PELARUTAN TOTAL MONASIT BANGKA
}

\author{
Noor Anis Kundari ${ }^{1}$, Riesna Prassanti ${ }^{2}$, Giezzella ${ }^{3}$ \\ 1) STTN-BATAN, Yogyakarta, Indonesia, nooranis@batan.go.id \\ 2) PTBGN-BATAN, Jakarta Selatan, Indonesia, riesna@batan.go.id \\ 3) STTN-BATAN, Yogyakarta, Indonesia, 011100287giezzella@gmail.com
}

\begin{abstract}
ABSTRAK
EKSTRAKSI DAN STRIPPING URANIUM HASIL PELARUTAN TOTAL MONASIT BANGKA. Penelitian pengolahan monasit di PTBGN-BATAN telah berhasil memisahkan logam tanah jarang dari unsur radioaktif dengan kemurnian yang tinggi, namun menghasilkan limbah berupa campuran logam tanah jarang, uranium, torium, dan unsur lain yang tidak terambil. Proses pengolahan limbah dapat dilakukan dengan memisahkan uranium terlebih dulu dengan metode ekstraksi menggunakan trioktil amin. Dalam penelitian ini dilakukan ekstraksi uranium dengan trioktil amina dan stripping uranium dengan $\mathrm{H}_{2} \mathrm{SO}_{4}$ untuk menentukan nilai koefisien distribusi (Kd) U, Th, $\mathrm{LTJ}_{2} \mathrm{O}_{3}$, dan $\mathrm{PO}_{4}$. Nilai Kd yang diperoleh digunakan untuk menentukan jumlah tingkat ekstraksi-stripping yang dibutuhkan untuk mengambil 95\% uranium dari limbah umpan, dengan ekstraksi dan stripping dari kondisi yang telah diperoleh. Nilai Kd dihitung berdasarkan persamaan Nernst, sedangkan jumlah stage ekstraksi-stripping dihitung berdasarkan nilai Kd uranium dengan metode McCabe Thiele. Penelitian ini menghasilkan nilai $\mathrm{Kd}$ pada ekstraksi dengan komposisi ekstraktan TOA:Kerosen:isodekanol $=5: 92: 3$ adalah $\mathrm{U}=3,42 ; \mathrm{Th}=0,02 ; \mathrm{LTJ}_{2} \mathrm{O}_{3}=0,07 ;$ dan $\mathrm{PO}_{4}=0,10 . \mathrm{Kd}$ pada stripping uranium menggunakan $\mathrm{H}_{2} \mathrm{SO}_{4} 3 \mathrm{M}$ adalah $\mathrm{U}=0,13$ dan $\mathrm{Th}=2,21$. Berdasarkan nilai $\mathrm{Kd}$ ini, jumlah tingkat teoretis ekstraksi dan stripping untuk memperoleh uranium sebanyak $95 \%$ adalah 7 tingkat ekstraksi pada $\mathrm{A} / \mathrm{O}=2$ dan 6 tingkat stripping pada $\mathrm{A} / \mathrm{O}=1 / 5$.
\end{abstract}

Kata kunci: ekstraksi-stripping, uranium, penentuan jumlah stage, pelarutan total monasit Bangka

\begin{abstract}
URANIUM EXTRACTION AND STRIPPING FROM TOTAL DISOLUTION OF BANGKA MONAZITE. Monazite processing research in PTBGN-BATAN has succeeded in separating the rare earth metals of radioactive elements with high purity, but produced waste in the form of a mixture of rare earth metals, uranium, thorium, and other elements that were not recovered. Waste treatment process has been carried out by first separating uranium from others by using extraction method with trioctyl amine. In this research, the extraction of uranium with trioctyl amines and stripping uranium with $\mathrm{H}_{2} \mathrm{SO}_{4}$ was done to determine the value of the distribution coefficient $(\mathrm{Kd})$ of $\mathrm{U}, \mathrm{Th}, \mathrm{LTJ}_{2} \mathrm{O}_{3}$, and $\mathrm{PO}_{4}$, and to determine the number of extraction-stripping stages required to take $95 \%$ of uranium from the waste feed, to the extraction and stripping of the conditions that had been obtained. Kd was calculated based on the Nernst equation, then the number of theoretical stage of extraction stripping was calculated based on the value of Kd U with McCabe Thiele method. This research resulted in Kd values on extraction with extractant ratio TOA:kerosene: isodekanol $=5: 92: 3$ is $U=3.42 ; \mathrm{Th}=0.02 ; \mathrm{LTJ}_{2} \mathrm{O}_{3}=0.07$; and $\mathrm{PO}_{4}=0.10 . \mathrm{Kd}$ on uranium stripping using $\mathrm{H}_{2} \mathrm{SO}_{4} 3 \mathrm{M}$ is $U=0.013$ and $\mathrm{Th}=2.21$. Based on this $\mathrm{Kd}$ value specified number of theoretical stages of extraction and stripping to obtain uranium as much as 95\%,based on calculation, the number of stages of extraction is 7 stage for comparison $A / O=2$ and 6 stage stripping at $A / O=1 / 5$.
\end{abstract}

Keywords: extraction-stripping, uranium, number of stages calculation, total dissolution of Bangka monazite 


\section{PENDAHULUAN}

Penelitian pengolahan monasit di PTBGNBATAN telah berhasil memisahkan logam tanah jarang dari unsur radioaktif dengan kemurnian tinggi, namun menghasilkan limbah berupa campuran logam tanah jarang (LTJ), uranium (U), torium (Th), dan unsur lain yang tidak terambil. Proses pengolahan limbah dapat dilakukan dengan memisahkan uranium terlebih dulu dengan metode ekstraksi menggunakan trioktil amin.

Hasil penelitian sebelumnya menunjukkan bahwa kondisi optimum ekstraksi, yaitu pada $\mathrm{pH}$ umpan 1,5, dengan perbandingan $\mathrm{O} / \mathrm{A}=5$ dan waktu ekstraksi 5 menit, $100 \%$ U dapat terekstrak, tetapi Th juga ikut terekstrak sebesar 32,44\%. [1]

Untuk keperluan perancangan unit ekstraksi diperlukan nilai koefisien distribusi (Kd). Nilai ini dipengaruhi oleh jenis ekstraktan, komposisi, dan suhu. Dalam penelitian ini dilakukan variasi konsentrasi ekstraktan dan konsentrasi stripper dalam proses ekstraksi-stripping untuk menentukan koefisien distribusi pada setiap variasi komposisi ekstraktan dan koefisien distribusi stripping pada setiap variasi konsentrasi stripper. Berdasarkan nilai koefisien distribusi dapat ditentukan jumlah stage yang dibutuhkan untuk memperoleh uranium dengan recovery 95\%. Penelitian ini perlu dilakukan karena minimnya data koefisien distribusi untuk ekstraksi uranium, dan beberapa data koefisien distribusi yang ditemui sulit untuk dijadikan data perancangan karena informasi yang ditampilkan kurang lengkap.

\section{TEORI}

\section{Pengolahan Monasit Bangka}

Pengolahan monasit di PTBGN-BATAN dimaksudkan untuk mendapatkan uranium. Proses ini terdiri atas beberapa tahapan, yaitu dekomposisi pasir monasit, pelarutan parsial, pengendapan $\mathrm{U}$ dan $\mathrm{Th}$, pelarutan total, ekstraksi-stripping, dan pengendapan U. Dekomposisi pasir monasit dengan $\mathrm{NaOH}$ bertujuan untuk memecah struktur ikatan monasit dan memisahkan fosfat melalui proses pemisahan padat cair [2]. Pelarutan parsial dengan $\mathrm{HCl}$ pada $\mathrm{pH} 3,7$ bertujuan untuk melarutkan logam tanah jarang sebanyak mungkin, namun $U$ dan Th terlarut seminimal mungkin [3]. Pengendapan dengan $\mathrm{NH}_{4} \mathrm{OH}$ pada $\mathrm{pH}$ 6,3 bertujuan untuk mengendapkan uranium dan torium sebanyak-banyaknya. Endapan dari proses pengendapan $\mathrm{NH}_{4} \mathrm{OH}$ dilarutkan dengan $\mathrm{H}_{2} \mathrm{SO}_{4}$ pekat, kemudian digunakan sebagai umpan ekstraksi. Pelarutan menggunakan $\mathrm{H}_{2} \mathrm{SO}_{4}$ ini merupakan pelarutan total yang berfungsi melarutkan semua endapan.

\section{Ekstraksi Stripping Uranium}

Ekstraksi uranium adalah proses pemisahan uranium dari campuran larutan oleh suatu pelarut organik yang tidak saling melarutkan. Selama proses ekstraksi, uranium akan terdistribusi di antara dua pelarut (fase organik dan fase cair) sesuai hukum distribusi Nernst. [4]

Uranium dalam larutan dapat berbentuk senyawa kompleks netral, anion, maupun kation. Berdasarkan hal tersebut, pelarut organik dibagi menjadi 3 (tiga) kategori. Kategori pertama adalah eter, trialkil fosfat, dan trialkil fosfin oksida yang mengekstrak kompleks netral; kategori kedua adalah alkil amin yang mengekstrak kompleks anion, dan kategori ketiga adalah alkyl orthophosporic acid dan alkyl pyro-phosporic acid yang mengekstrak kation. [5]

Uranium maupun torium terlarut dalam asam sulfat membentuk kompleks anion, yaitu $\mathrm{UO}_{2}\left(\mathrm{SO}_{4}\right)_{3}{ }^{4-}$ atau $\mathrm{UO}_{2}\left(\mathrm{SO}_{4}\right)_{3}{ }^{2-}$, dan $\mathrm{Th}\left(\mathrm{SO}_{4}\right)_{3}{ }^{2-}$. Uranil sulfat terekstrak sangat baik dengan jenis amina, sedangkan torium sulfat tidak banyak terekstrak. Torium sulfat lebih baik diekstrak dengan jenis amina primer [6]. Koefisien distribusi $(\mathrm{Kd})$ unsur dalam amina tersier adalah uranium 140 , torium $<0,03$, dan cerium <0,01 [7]. Berdasarkan nilai $\mathrm{Kd}$ ini, diketahui bahwa nilai $\mathrm{Kd} \mathrm{U}$ memiliki perbedaan cukup jauh daripada $\mathrm{Kd}$ Th dan $\mathrm{Kd}$ Ce sehingga amina tersier cukup selektif terhadap uranium.

Ekstraksi uranium juga dapat dilakukan menggunakan TBP dalam suasana asam nitrat. Pada 30\% TBP dalam kerosen, nilai $\mathrm{Kd} \mathrm{U}=$ 2,030 dan $\mathrm{Kd} \mathrm{Th}=4,936$ [8]. Berdasarkan nilai tersebut, dapat diketahui bahwa Kd U dan Th memiliki nilai yang cukup dekat sehingga apabila dilakukan ekstraksi dengan TBP pada suasana asam nitrat maka $U$ dan $T h$ akan lebih sulit dipisahkan.

Proses ekstraksi selalu diikuti dengan stripping. Stripping bertujuan untuk mengambil kembali uranium dari fase organik ke fase air. Beberapa hal yang berpengaruh 
dalam proses stripping adalah jenis stripper, konsentrasi stripper, suhu, perbandingan O/A, dan waktu stripping.

Morais, dkk. (2005) meneliti efek konsentrasi $\mathrm{H}_{2} \mathrm{SO}_{4}$ pada stripping uranium pada kisaran 2,0-5,0 mol/l. Dalam kisaran ini efisiensi stripping uranium meningkat dari $24 \%$ menjadi $75 \%$, menunjukkan bahwa stripping uranium dari alamina 336 menggunakan $\mathrm{H}_{2} \mathrm{SO}_{4}$ harus dilakukan dalam konsentrasi asam yang tinggi. Hasil yang diperoleh menunjukkan bahwa koefisien distribusi uranium berkurang secara signifikan ketika konsentrasi $\mathrm{H}_{2} \mathrm{SO}_{4}$ lebih dari 3,5 mol/l. Penelitian ini menggunakan variasi waktu kontak antarfase antara 3 dan 10 menit. Berdasarkan pengamatan, diketahui bahwa 5 menit sudah cukup untuk mencapai keseimbangan logam antara fase [9].

Koefisien distribusi pada proses ekstraksi dan stripping dapat ditentukan berdasarkan rumus berikut.
Koefisien Distribusi $=\frac{\text { Kons.unsur dlm organik }}{\text { Kons.unsur dlm aqueous }}$

\section{Penentuan Jumlah Stage}

Penentuan jumlah stage dapat dilakukan dengan metode grafik McCabe Thiele. Penentuan dengan metode ini dapat dilakukan menggunakan grafik keseimbangan dan garis operasi yang diplotkan pada grafik konsentrasi solute dalam rafinat $(\mathrm{X})$ dan konsentrasi solute dalam ekstrak (Y). Grafik keseimbangan dapat dibuat apabila memiliki nilai koefisien distribusi ataupun nilai koefisien partisi yang didapatkan dari percobaan, sedangkan garis operasi dapat dibuat dengan menghubungkan dua koordinat, yaitu titik $\mathrm{P}\left(\mathrm{X}_{\mathrm{F}}, \mathrm{Y}_{1}\right)$ dan $\mathrm{Q}\left(\mathrm{X}_{\mathrm{n}}, \mathrm{Y}_{\mathrm{n}+1}\left(=\mathrm{Y}_{\mathrm{s}}\right)\right)$. Contoh grafik kesetimbangan dan garis operasi dapat dapat dilihat pada Gambar 1.

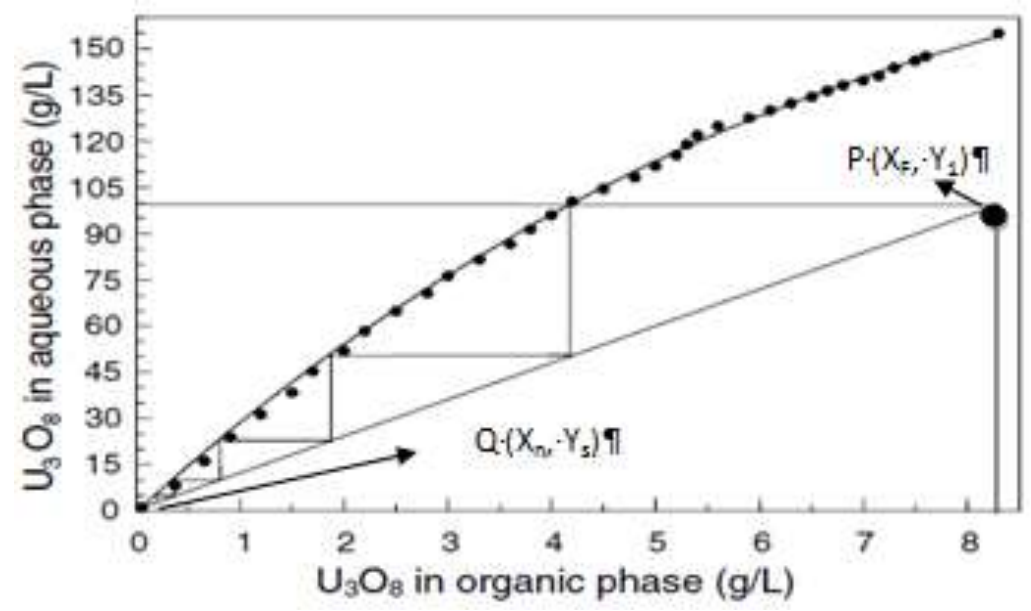

Gambar 1. Kurva Kesetimbangan dan Garis Operasi

Jumlah stage ditentukan dengan menarik garis dari titik $\mathrm{Q}$ ke arah vertikal sampai bersinggungan dengan kurva kesetimbangan, kemudian ditarik secara horizontal sampai mengenai garis operasi. Begitu seterusnya sampai pada puncak titik P. Banyaknya siku yang menyinggung kurva kesetimbangan merupakan jumlah stage secara teoretis [10].

\section{BAHAN DAN ALAT}

\section{Bahan}

1. Bahan yang digunakan dalam penelitian ini adalah umpan ekstraksi yang dibuat dari monasit Bangka, $\mathrm{NaOH}, \mathrm{HCl}, \mathrm{H}_{2} \mathrm{SO}_{4}$, $\mathrm{NH}_{4} \mathrm{OH}$, kertas saring, dan akuades.
Ekstraktan yang digunakan adalah trioktil amin, isodekanol, dan kerosen, dengan beberapa perbandingan.

2. Umpan ekstraksi dibuat dari monasit Bangka, $\mathrm{NaOH}, \mathrm{HCl}, \mathrm{H}_{2} \mathrm{SO}_{4}, \mathrm{NH}_{4} \mathrm{OH}$, kertas saring, dan akuades.

3. Trioktil amin, isodekanol, dan kerosen digunakan sebagai ekstraktan pada proses ekstraksi.

4. $\mathrm{H}_{2} \mathrm{SO}_{4}$ digunakan sebagai stripper pada proses stripping.

\section{Alat}

1. Alat yang digunakan pada saat proses adalah: gelas ukur, gelas beker, pengaduk magnetik, corong, corong pemisah, pipet 
tetes, mikropipet, timbangan analitik, labu ukur, bulb pipet, stopwatch, hot plate, $\mathrm{pH}$ meter, termometer, buret, dan pompa vakum.

2. Alat yang digunakan untuk analisis adalah: spektrofotometer UV-Vis, timbangan analitik, $\mathrm{pH}$ meter, dan furnace.

\section{LANGKAH KERJA}

\section{Ekstraksi Uranium}

Menentukan waktu setimbang. Larutan (U, Th, LTJ) sulfat dan ekstraktan dimasukkan ke dalam gelas beker dengan perbandingan $\mathrm{O} / \mathrm{A}=$ 1, $\mathrm{pH}$ umpan 1,5, dan perbandingan ekstraktan TOA:Kerosen:isodekanol $=5: 92: 3$. Larutan diekstraksi dengan variasi waktu $5,10,25,45$, dan 60 menit, kemudian dibiarkan terpisah selama 17 jam. Fase organik dan fase cair dipisahkan, kemudian fase cair dianalisis. Waktu setimbang digunakan sebagai waktu ekstraksi pada proses berikutnya.

Menentukan Kd berdasarkan variasi perbandingan konsentrasi ekstraktan. Larutan (U, Th, LTJ) sulfat dan ekstraktan dimasukkan ke dalam gelas beker dengan perbandingan $\mathrm{O} / \mathrm{A}=1$, $\mathrm{pH}$ umpan 1,5, dan variasi perbandingan ekstraktan TOA:kerosen:isodekanol $=3: 94: 3 ;$ 4:93:3; 5:92:3; 6:91:3; 7:90:3; 5:95:0; 5:93:2; 5:91:4; dan 5:90:5. Ekstraksi dilakukan sesuai dengan waktu setimbang, kemudian dilakukan pemisahan dengan corong pemisah. Fase organik dan fase cair yang telah dipisahkan kemudian dianalisis.

\section{Stripping Uranium}

Menentukan waktu setimbang. Fase organik hasil ekstraksi pada $\mathrm{pH} 1,5$ dan $\mathrm{A} / \mathrm{O}=1 / 5$ dengan perbandingan TOA:kerosen:isodekanol $=5: 92: 3$ di-stripping dengan $\mathrm{H}_{2} \mathrm{SO}_{4}$ pada perbandingan $\mathrm{A} / \mathrm{O}=1$ dan konsentrasi $\mathrm{H}_{2} \mathrm{SO}_{4}$ 2,5 M. Stripping dilakukan dengan variasi waktu 5, 10, 25, 45, dan 60 menit, kemudian dibiarkan selama 16 jam. Fase organik dan fase cair dipisahkan, kemudian fase cair dianalisis. Waktu setimbang digunakan sebagai waktu stripping pada proses berikutnya.

Menentukan Kd berdasarkan variasi konsentrasi stripper. Fase organik hasil ekstraksi di-stripping dengan $\mathrm{H}_{2} \mathrm{SO}_{4}$ pada perbandingan $\mathrm{A} / \mathrm{O}=1$ dan variasi konsentrasi $\mathrm{H}_{2} \mathrm{SO}_{4} 1,5 \mathrm{M}, 2 \mathrm{M}, 2,5 \mathrm{M}, 3 \mathrm{M}$, dan 3,5 M. Stripping dilakukan sesuai dengan waktu setimbang yang telah ditentukan. Fase organik dan fase cair dipisahkan, kemudian fase cair dianalisis.

\section{HASIL DAN PEMBAHASAN}

\section{Nilai Kd Ekstraksi dan Stripping}

Kd unsur pada proses ekstraksi maupun stripping dapat dihitung apabila ekstraksi maupun stripping yang dilakukan telah mencapai kesetimbangan. Oleh karena itu, dilakukan penentuan waktu setimbang terlebih dulu dengan variasi waktu pengadukan, kemudian dibiarkan terpisah selama waktu tertentu. Waktu pemisahan untuk ekstraksi adalah selama 17 jam dan untuk stripping adalah 16 jam.

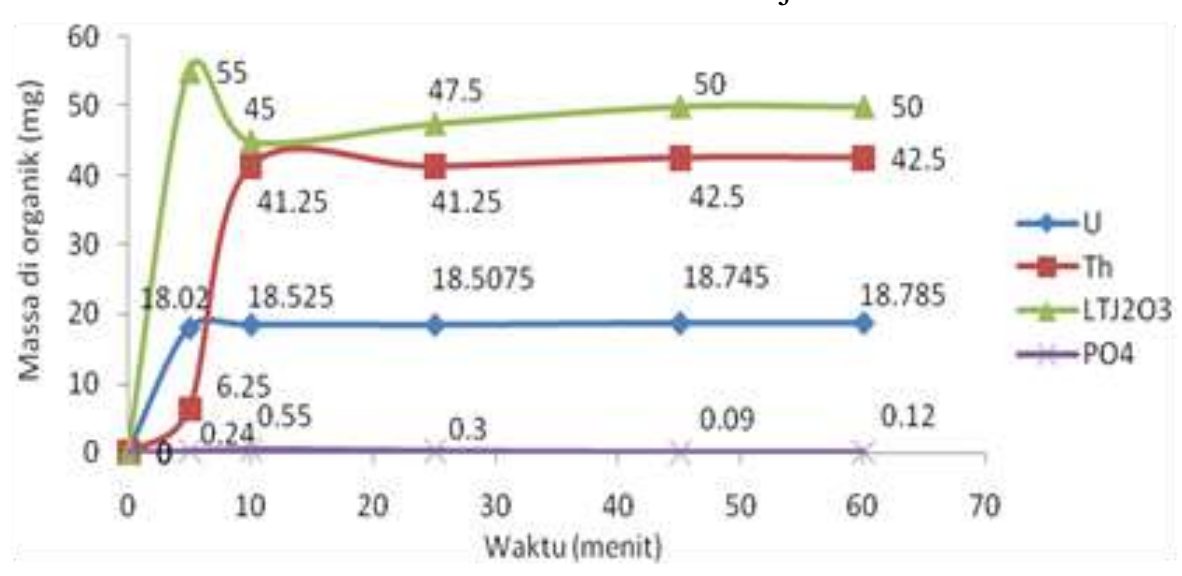

Gambar 2. Pengaruh Waktu Pengadukan Terhadap Massa Terekstrak pada Proses Ekstraksi 


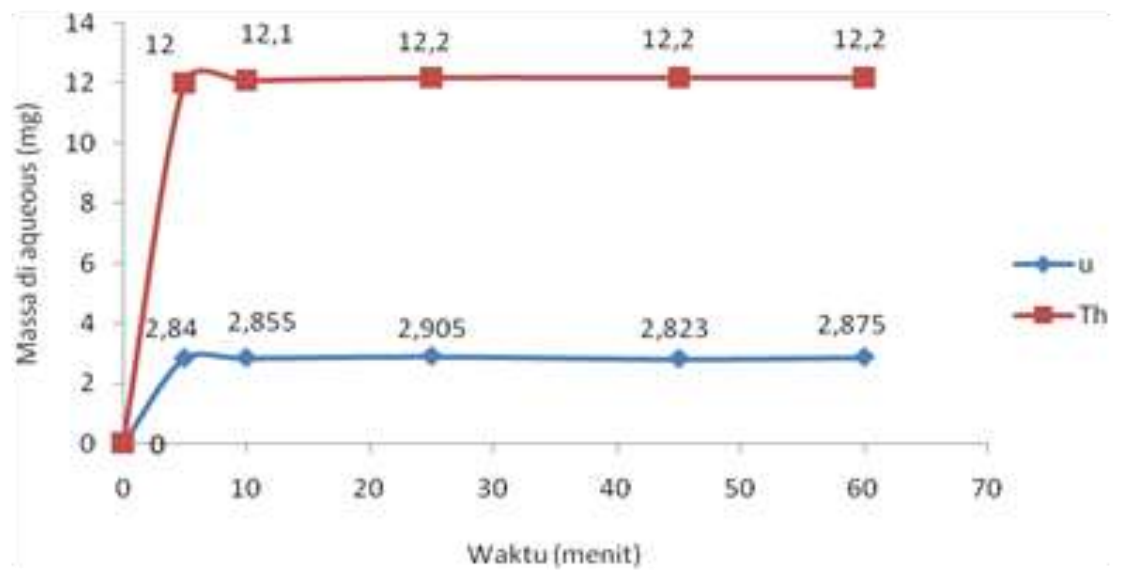

Gambar 3. Pengaruh Waktu Pengadukan Terhadap Massa Terekstrak pada Proses Stripping

Berdasarkan Gambar 2 dan Gambar 3, dapat ditentukan waktu setimbang untuk ekstraksi adalah pengadukan selama 10 menit kemudian dibiarkan terpisah selama 17 jam dan waktu setimbang stripping adalah pengadukan selama 5 menit dan dibiarkan terpisah selama 16 jam. Setiap variasi pada ekstraksi maupun stripping dilakukan pada waktu setimbang. Berdasarkan percobaan diperoleh nilai Kd pada ekstraksi dan stripping seperti ditampilkan pada Tabel 1, Tabel 2, dan Tabel 3.

Tabel 1 dan Tabel 2 digunakan sebagai data untuk mengetahui pengaruh komposisi ekstraktan terhadap Kd uranium. Adapun Tabel 3 digunakan sebagai data untuk mengetahui pengaruh konsentrasi stripper terhadap $\mathrm{Kd}$ uranium.

Tabel 1. Kd pada Ekstraksi Variasi TOA*

\begin{tabular}{ccccc}
\hline \multirow{2}{*}{$\begin{array}{c}\text { Perbandingan ekstraktan } \\
\text { (konsentrasi TOA) }\end{array}$} & $\mathrm{U}$ & $\mathrm{Th}$ & $\mathrm{LTJ}_{2} \mathrm{O}_{3}$ & $\mathrm{PO}_{4}$ \\
\hline $3-94: 3(0,0687 \mathrm{M})$ & 1,34 & 0,015 & 0,057 & 0,094 \\
$4-93-3(0,0916 \mathrm{M})$ & 2,52 & 0,025 & 0,063 & 0,095 \\
$5: 92-3(0,1145 \mathrm{M})$ & 3,42 & 0,023 & 0,065 & 0,097 \\
$6-91-3(0,1374 \mathrm{M})$ & 6,41 & 0,031 & 0,040 & 0,096 \\
$7-90-3(0,1603 \mathrm{M})$ & 7,30 & 0,034 & 0,044 & 0,103 \\
\hline *isodekanol $=3 \%$ volume dalam kerosen; $\mathrm{A} 0=1 ; \mathrm{pH}$ umpan $=1,5$
\end{tabular}

Tabel 2. Kd pada Ekstraksi Variasi Isodekanol*

\begin{tabular}{|c|c|c|c|c|}
\hline \multirow{2}{*}{$\begin{array}{l}\text { Perbandingan ekstraktan } \\
\text { (\% volume isodekanol) }\end{array}$} & \multicolumn{4}{|c|}{ Koefisien distnibusi } \\
\hline & $\mathrm{U}$ & Th & $\mathrm{LTJ}_{2} \mathrm{O}_{3}$ & $\mathrm{PO}_{4}$ \\
\hline $5-95: 0(0)$ & 3,13 & 0,015 & 0,073 & 0,176 \\
\hline $5-93-2(2)$ & 5,06 & 0,019 & 0,059 & 0,174 \\
\hline $5-92-3(3)$ & 3,42 & 0,023 & 0,065 & 0,097 \\
\hline $5-91: 4(4)$ & 3,39 & 0,053 & 0,048 & 0,139 \\
\hline $5-90-5(5)$ & 2,69 & 0,051 & 0,046 & 0,116 \\
\hline
\end{tabular}

Tabel 3. Kd pada Stripping Variasi Konsentrasi Stripper

\begin{tabular}{ccc}
\hline Konsentrasi $\mathrm{H}_{2} \mathrm{SO}_{4}$ & \multicolumn{2}{c}{ Koefisien Distribusi } \\
\cline { 2 - 3 }$(\mathrm{M})$ & $\mathrm{U}$ & Th \\
\hline 0 & 79,45 & 4,87 \\
0,5 & 33,48 & 2,16 \\
1 & 7,15 & 1,93 \\
1,5 & 3,27 & 1,61 \\
2 & 1,07 & 1,83 \\
2,5 & 0,46 & 2,05 \\
3 & 0,13 & 2,21 \\
3,5 & 0,18 & 3,05 \\
\hline *organik TOA:Kerosen:Isodekanol $=5: 92: 3 ; \mathrm{A} / \mathrm{O}=1$
\end{tabular}

\section{Pengaruh Perbandingan Konsentrasi Ekstraktan Terhadap Kd Uranium}

Ekstraktan yang digunakan dalam proses ekstraksi adalah trioktil amin (TOA) dalam kerosen yang dimodifikasi dengan isodekanol. Pengaruh perbandingan antara TOA, kerosen, dan isodekanol dalam ekstraktan terhadap koefisien distribusi uranium diteliti dengan memvariasikan volume TOA dan volume isodekanol. Pada variasi volume TOA, isodekanol disamakan. Sementara pada variasi volume isodekanol, volume TOA disamakan. Volume kerosen mengikuti volume TOA dan isodekanol dengan jumlah perbandingan volume TOA:kerosen:isodekanol harus $100 \%$. Data koefisien distribusi dibuat menjadi grafik yang ditunjukkan pada Gambar 4. 


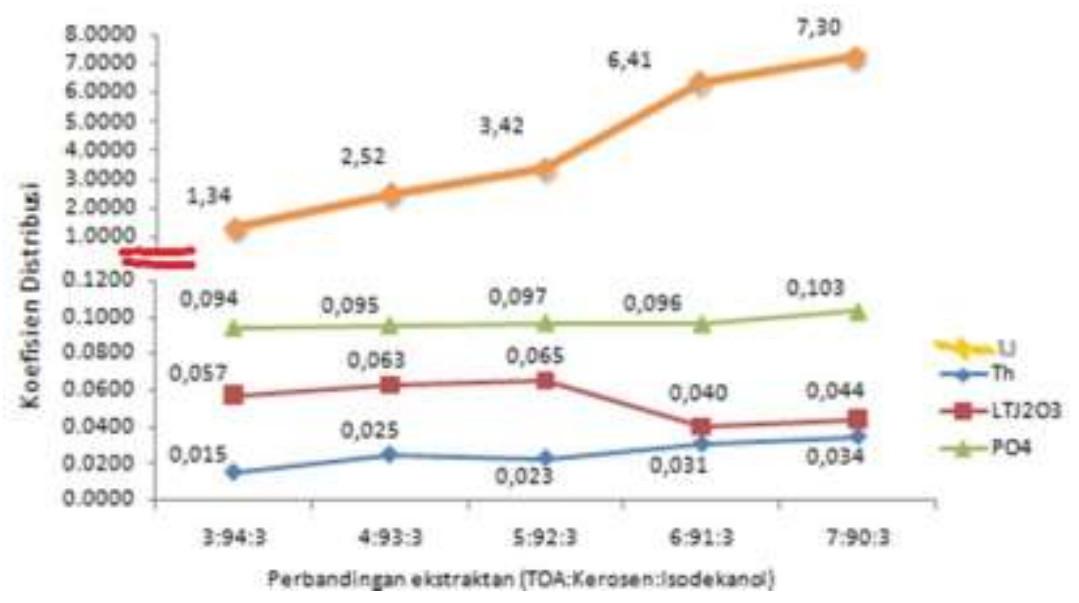

Gambar 4. Hubungan Perbandingan Ekstraktan (Variasi Konsentrasi TOA) dengan Kd U, Th, LTJ $\mathrm{O}_{3}$, dan $\mathrm{PO}_{4}(\mathrm{~A} / \mathrm{O}=1, \mathrm{pH}$ Umpan 1,5)

Berdasarkan Gambar 4 dapat diketahui bahwa Kd uranium semakin meningkat dengan bertambahnya konsentrasi TOA dalam campuran. Ini menunjukkan bahwa konsentrasi TOA dalam campuran ekstraktan sangat berpengaruh terhadap kemampuan ekstraktan untuk mengekstrak uranium. Ritcey (2006) menyebutkan bahwa TOA yang digunakan pada sebagian besar ekstraksi uranium adalah antara 3-5\% volume atau sekitar 0,05 M sampai $0,1 \mathrm{M}$ sudah cukup untuk mengekstrak uranium [11].

Gambar 4 juga memperlihatkan bahwa Kd Th dan $\mathrm{PO}_{4}$ meningkat seiring dengan bertambahnya konsentrasi TOA. Hal ini menunjukkan bahwa penambahan konsentrasi TOA pada ekstraksi dari larutan asam sulfat menggunakan TOA juga dapat meningkatkan jumlah Th dan $\mathrm{PO}_{4}$ yang terekstrak di fase organik. Meskipun demikian, peningkatan nilai Kd keduanya cukup rendah. Peningkatan persentase volume TOA dari 3\% menjadi 5\% volume menyebabkan nilai $\mathrm{Kd} \quad \mathrm{LTJ}_{2} \mathrm{O}_{3}$ mengalami sedikit kenaikan, kemudian turun pada penambahan $6 \%$ volume TOA. Perubahan nilai $\mathrm{Kd} \mathrm{Th}, \mathrm{LTJ}_{2} \mathrm{O}_{3}$, dan $\mathrm{PO}_{4}$ cukup kecil sehingga penambahan persentase volume TOA tidak terlalu mempengaruhi nilai $\mathrm{Kd}$ ketiga unsur tersebut.

Berdasarkan Gambar 4 juga diketahui bahwa terdapat perbedaan yang jauh antara nilai $\mathrm{Kd} \mathrm{U}$ dengan $\mathrm{Th}, \mathrm{LTJ}_{2} \mathrm{O}_{3}$, dan $\mathrm{PO}_{4}$. Hal ini menunjukkan bahwa TOA selektif terhadap uranium. Namun apabila konsentrasi Th, $\mathrm{LTJ}_{2} \mathrm{O}_{3}$, dan $\mathrm{PO}_{4}$ dalam umpan jauh lebih besar daripada konsentrasi U maka pemisahan cukup sulit dilakukan. Berdasarkan nilai $\mathrm{Kd}$ ketiga unsur tersebut dapat dihitung kandungan Th, $\mathrm{LTJ}_{2} \mathrm{O}_{3}$, dan $\mathrm{PO}_{4}$ (pengotor) yang keluar dari proses.

Pengaruh persentase volume isodekanol pada perbandingan ekstraktan ditampilkan dalam Gambar 5.

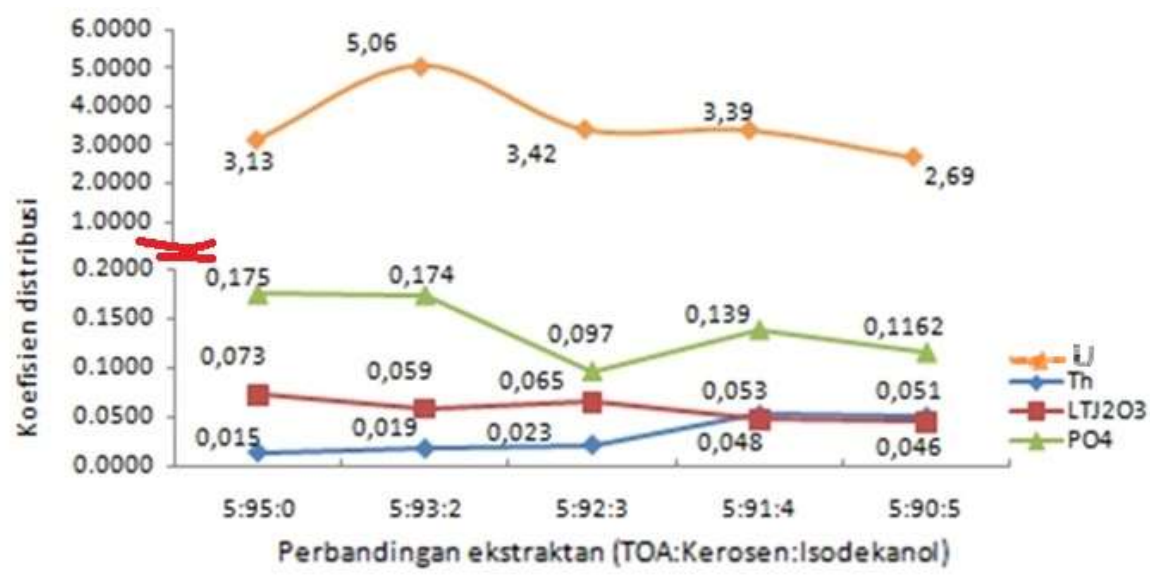

Gambar 5. Hubungan Perbandingan Ekstraktan (Variasi \% Volume Isodekanol) Terhadap Kd U, Th, $\mathrm{LTJ}_{2} \mathrm{O}_{3}$, dan $\mathrm{PO}_{4}(\mathrm{~A} / \mathrm{O}=1$, pH Umpan 1,5) 
Penambahan alkil alkohol cukup efektif untuk membantu mengurangi terbentuknya emulsi. Isodekanol dengan $2-5 \%$ volume biasa digunakan sebagai modifier untuk ekstraksi uranium dengan amin tersier. Berdasarkan Gambar 5 diketahui bahwa $\mathrm{Kd}$ uranium meningkat pada penambahan $2 \%$ volume isodekanol, yaitu dari 3,13 menjadi 5,06, namun mengalami penurunan pada penambahan 3\%, 4\%, dan 5\% volume isodekanol, seperti yang telah dikatakan oleh Coleman, dkk. (1958) bahwa kehadiran isodekanol bisa meningkatkan uranium yang terekstak sampai batas tertentu [12]. Hal ini disebutkan juga oleh Crouse \& Brown (1959), yang mengatakan bahwa efisiensi ekstraksi akan berkurang apabila ke dalam ekstraktan ditambahkan sejumlah besar alkohol rantai panjang seperti isodekanol, namun penambahan $2-5 \%$ volume biasanya hanya menyebabkan penurunan yang kecil [9].

Gambar 5 menunjukkan bahwa nilai $\mathrm{Kd}$ $\mathrm{LTJ}_{2} \mathrm{O}_{3}$ dan $\mathrm{PO}_{4}$ mengalami penurunan dengan bertambahnya persentase volume isodekanol dalam ekstraktan. Berbeda dengan Kd Th yang mengalami peningkatan dengan bertambahnya persentase volume isodekanol. Berdasarkan nilai $\mathrm{Kd}$ ketiga unsur tersebut, dapat dihitung kandungan $\mathrm{Th}, \mathrm{LTJ}_{2} \mathrm{O}_{3}$, dan $\mathrm{PO}_{4}$ (pengotor) yang keluar dari proses.

Berdasarkan Gambar 4 dan Gambar 5, dapat diketahui bahwa pada 5\% volume TOA, nilai $\mathrm{Kd} \mathrm{U}$ dengan penambahan $2 \%$ volume isodekanol $(\mathrm{Kd}=5,06)$ lebih besar daripada nilai $\mathrm{Kd} \mathrm{U}$ pada penambahan $3 \%$ volume isodekanol $(\mathrm{Kd}=3,42)$. Sementara nilai $\mathrm{Kd} \mathrm{U}$ pada penambahan $6 \%$ volume TOA dengan $3 \%$ volume isodekanol $(\mathrm{Kd}=6,41)$ memiliki perbedaan yang cukup rendah dengan nilai $\mathrm{Kd}$ $\mathrm{U}$ pada $5 \%$ volume TOA dengan penambahan $2 \%$ volume isodekanol $(\mathrm{Kd}=5,06)$. Dengan demikian, dapat dikatakan bahwa ekstraksi uranium dengan menggunakan ekstraktan TOA:kerosen:isodekanol baik digunakan pada penambahan $5 \%$ volume TOA dan $2 \%$ volume isodekanol atau pada perbandingan TOA:kerosen:isodekanol $=5: 93: 2$. Meskipun demikian, penggunaan ekstraktan juga harus memperhatikan kekentalan TOA dalam ekstraktan. Apabila penambahan persentase isodekanol terlalu kecil maka kekentalan TOA dalam ekstraktan akan lebih besar dan dapat memperbesar kemungkinan terjadinya emulsi yang tidak diharapkan.

\section{Pengaruh Konsentrasi Stripper Terhadap Kd Uranium}

Pada penelitian ini, stripping dilakukan dari ekstraktan TOA:kerosen:isodekanol = 5:92:3 dengan $\mathrm{H}_{2} \mathrm{SO}_{4}$ sebagai stripper. Koefisien distribusi stripping yang sebelumnya telah ditampilkan pada Tabel 3 dibuat menjadi Grafik yang ditunjukkan pada Gambar 6 .

Dari Gambar 6 dapat diketahui bahwa pada stripping uranium menggunakan $\mathrm{H}_{2} \mathrm{SO}_{4}$ nilai $\mathrm{Kd} \mathrm{U}$ menurun dari konsentrasi 0 sampai dengan $3 \mathrm{M}$, kemudian mengalami peningkatan pada konsentrasi $\mathrm{H}_{2} \mathrm{SO}_{4} 3,5 \mathrm{M}$. Nilai $\mathrm{Kd} \mathrm{Th}$ juga mengalami penurunan pada konsentrasi $\mathrm{H}_{2} \mathrm{SO}_{4} 0$ sampai dengan $1,5 \mathrm{M}$, kemudian mengalami peningkatan. Hal ini menunjukkan bahwa uranium akan lebih banyak terambil pada konsentrasi stripper yang tinggi (keasaman tinggi), namun ada batasan tingkat keasaman atau konsentrasi stripper yang baik dalam stripping uranium, dalam hal ini pada konsentrasi 3 M. Berdasarkan penjelasan Gambar 6, torium akan banyak terambil pada konsentrasi asam yang rendah. Pada konsentrasi stripper yang tinggi (keasaman tinggi) torium akan lebih stabil dalam fase organik sehingga kelarutannya dalam stripper cukup rendah. Hal ini dikarenakan ekstraksi torium baik dilakukan pada keasaman tinggi sehingga untuk mengembalikan torium ke fase cair harus pada konsentrasi asam rendah.

Nilai $\mathrm{Kd}$ Th pada konsentrasi $\mathrm{H}_{2} \mathrm{SO}_{4} 0$ sampai dengan 1,5 $\mathrm{M}$ lebih kecil daripada nilai $\mathrm{Kd} \mathrm{U}$, sedangkan pada konsentrasi $\mathrm{H}_{2} \mathrm{SO}_{4} 2 \mathrm{M}$ sampai dengan $3 \mathrm{M}$ diketahui bahwa nilai $\mathrm{Kd}$ $\mathrm{U}$ lebih kecil daripada nilai $\mathrm{Kd} \mathrm{Th}$. Hal ini menunjukkan, apabila konsentrasi $\mathrm{U}$ dan Th dalam umpan sama maka pada rentang konsentrasi $\mathrm{H}_{2} \mathrm{SO}_{4} 0$ sampai $1,5 \mathrm{M}$ Th akan lebih banyak terambil daripada $\mathrm{U}$, sedangkan pada konsentrasi $\mathrm{H}_{2} \mathrm{SO}_{4} 2 \mathrm{M}$ sampai $3 \mathrm{M}$, uranium akan terambil lebih banyak. Perbedaan nilai $\mathrm{Kd}$ yang cukup signifikan antara Th dan $\mathrm{U}$ terdapat pada konsentrasi $\mathrm{H}_{2} \mathrm{SO}_{4} 3 \mathrm{M}$ (nilai $\mathrm{Kd} \mathrm{U}=0,13$ dan nilai $\mathrm{Kd} \mathrm{Th}$ $=2,21$ ). Pada konsentrasi ini, nilai Kd U lebih kecil daripada $\mathrm{Kd}$ Th sehingga jika kandungan $\mathrm{U}$ dan Th dalam umpan sama, uranium akan lebih banyak terambil. Perbedaan nilai yang sangat signifikan juga terdapat pada konsentrasi $\mathrm{H}_{2} \mathrm{SO}_{4}$ nol (dalam hal ini stripper yang digunakan adalah aquabidest). Pada konsentasi nol, nilai $\mathrm{Kd} \mathrm{Th}=4,87$ dan $\mathrm{U}=$ 79,45 . Pada keadaan ini, nilai Kd U jauh lebih 
besar daripada nilai $\mathrm{Kd}$ Th sehingga Th yang terambil akan lebih banyak daripada $U$. Berdasarkan penjelasan di atas dapat diketahui bahwa stripping uranium dari ekstraktan TOA:kerosen:isodekanol (5:92:3) baik dilakukan pada konsentrasi $\mathrm{H}_{2} \mathrm{SO}_{4} 3 \mathrm{M}$, sedangkan stripping untuk mendapatkan torium baik dilakukan menggunakan aquabidest (konsentrasi $\mathrm{H}_{2} \mathrm{SO}_{4}$ nol). Pada proses ekstraksi dan stripping, dapat dipertimbangkan untuk melakukan penambahan tahap scrubbing menggunakan aquabidest terlebih dulu untuk mengurangi kandungan Th dalam fase organik, kemudian fase organik di-stripping menggunakan $\mathrm{H}_{2} \mathrm{SO}_{4}$ $3 \mathrm{M}$ untuk mengambil uranium.

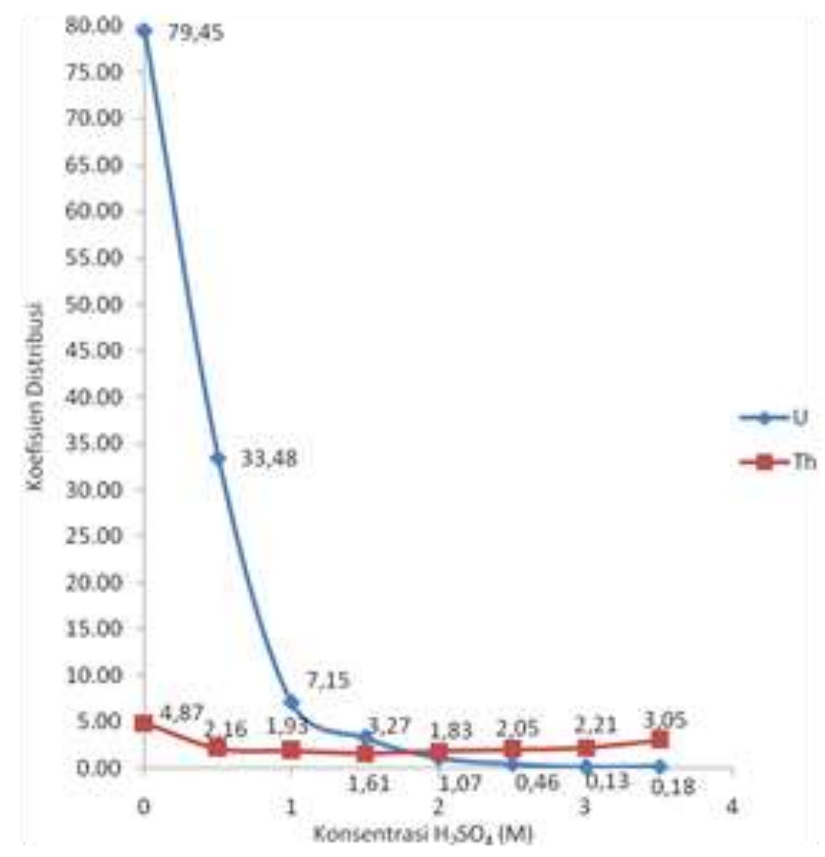

Gambar 6. Hubungan Konsentrasi Stripper dengan Kd U dan Kd Th

\section{Jumlah Stage Ekstraksi dan Stripping}

Kandungan unsur yang masuk ke dalam ekstraksi adalah $\mathrm{U}=1700 \mathrm{mg} / \mathrm{l} ; \mathrm{Th}=46 \mathrm{~g} / \mathrm{l}$; $\mathrm{LTJ}_{2} \mathrm{O}_{3}=90,38 \mathrm{~g} / \mathrm{l} ; \mathrm{PO}_{4}=42,64 \mathrm{mg} / \mathrm{l}$. Untuk mendapatkan recovery $95 \%$ uranium, dilakukan perhitungan recovery pada ekstraksi dan stripping. Berdasarkan perhitungan, recovery yang ingin dicapai pada ekstraksi adalah $99 \%$ dan pada stripping adalah $96 \%$ sehingga diperoleh recovery uranium $95 \%$. Jumlah stage yang dibutuhkan untuk memperoleh recovery tersebut dihitung berdasarkan nilai $\mathrm{Kd}$ ekstraksi pada perbandingan TOA:kerosen:isodekanol 5:92:3 $(\mathrm{Kd} \mathrm{U}=3,42)$ dan nilai $\mathrm{Kd}$ stripping pada konsentrasi $\quad \mathrm{H}_{2} \mathrm{SO}_{4} \quad 3 \quad \mathrm{M} \quad(\mathrm{Kd} \quad \mathrm{U}=0,13)$ menggunakan metode McCabe Thiele berdasarkan konsentrasi.

Jumlah stage teoretis untuk proses ekstraksi dihitung untuk variasi perbandingan volume cairan umpan yang masuk dan volume ekstraktan $(\mathrm{A} / \mathrm{O})=1$ dan 2. Jumlah stage untuk $\mathrm{A} / \mathrm{O}=1$ ditunjukkan pada Gambar 7, sedangkan jumlah stage untuk $\mathrm{A} / \mathrm{O}=2$ ditunjukkan pada Gambar 8. 


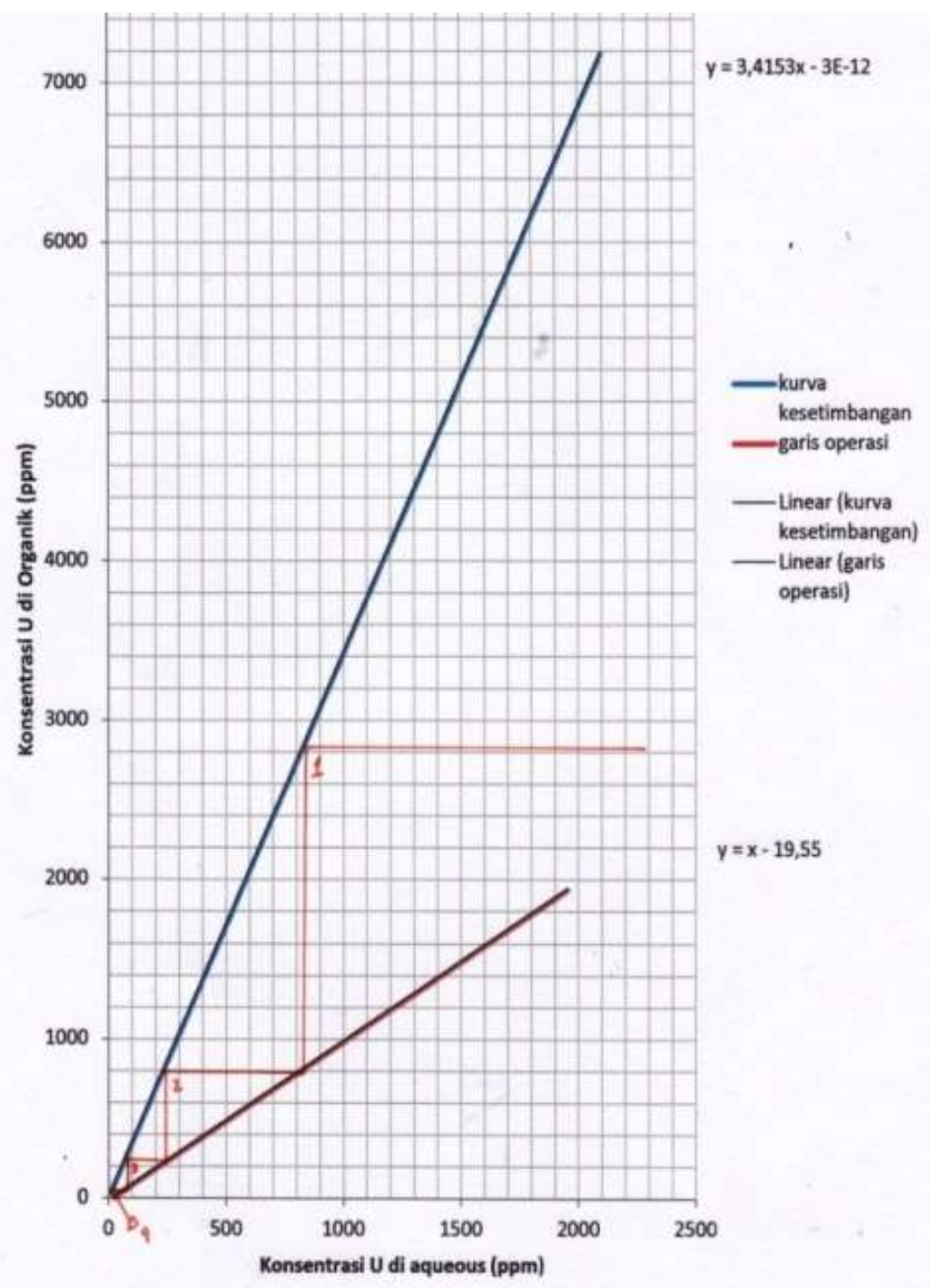

Gambar 7. Kurva Kesetimbangan dan Garis Operasi pada Ekstraksi dengan $\mathrm{A} / \mathrm{O}=1$

Berdasarkan Gambar 7 dan Gambar 8 dapat diketahui bahwa stage yang dibutuhkan pada ekstraksi dengan perbandingan $\mathrm{A} / \mathrm{O}=1$ adalah sebanyak 4 stage, sedangkan jumlah stage yang dibutuhkan pada perbandingan $\mathrm{A} / \mathrm{O}$ $=2$ adalah sebanyak 7 stage. Perbandingan A/O mempengaruhi konsentrasi yang keluar dari proses ekstraksi. Semakin tinggi perbandingan $\mathrm{A} / \mathrm{O}$ pada saat ekstraksi maka konsentrasi uranium dalam fase organik menjadi semakin tinggi. Konsentrasi fase organik yang terlalu tinggi dapat menyebabkan efisiensi proses stripping berkurang. Berdasarkan nilai Kd dan jumlah stage yang terdapat pada pembahasan sebelumnya, kandungan pengotor yang keluar dari proses ekstraksi dapat dihitung. Berdasarkan perhitungan diperoleh kandungan pengotor dalam ekstraktan yang keluar dari proses, seperti ditampilkan pada Tabel 4. 


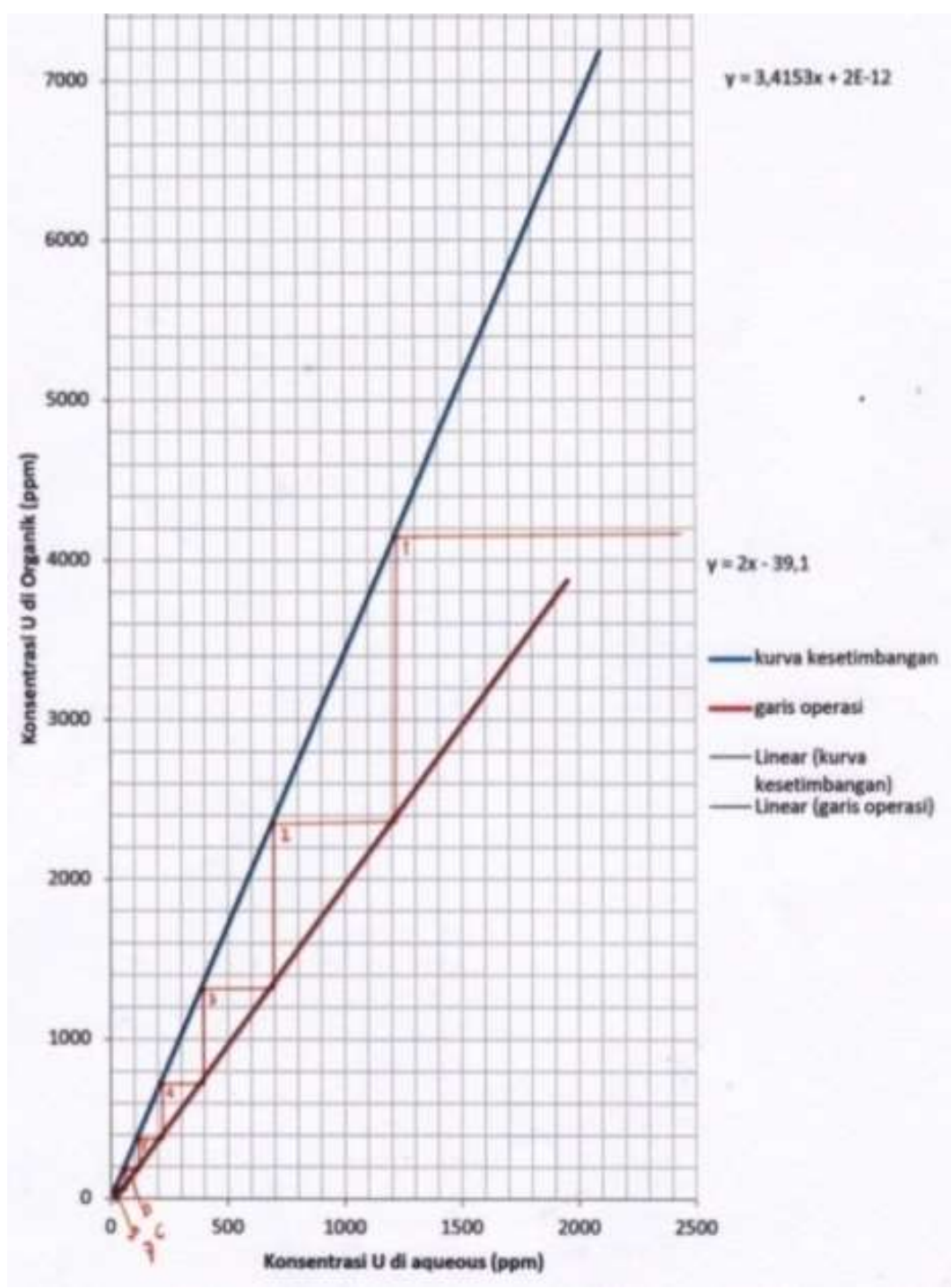

Gambar 8. Kurva Kesetimbangan dan Garis Operasi pada Ekstraksi Dengan A/O = 2

Tabel 4. Kandungan Uranium dan Pengotor pada Hasil Ekstraksi

\begin{tabular}{cccccc}
\hline & & \multicolumn{4}{c}{ Kandungan Unsur } \\
\cline { 3 - 6 } A/O & Stage & $\begin{array}{c}\mathbf{U} \\
(\mathbf{m g} / \mathbf{l})\end{array}$ & $\begin{array}{c}\mathrm{Th} \\
(\mathbf{g} / \mathbf{l})\end{array}$ & $\begin{array}{c}\mathrm{LTJ}_{2} \mathrm{O}_{3} \\
(\mathbf{g} / \mathbf{l})\end{array}$ & $\begin{array}{c}\mathbf{P O}_{4} \\
(\mathbf{m g} / \mathbf{l})\end{array}$ \\
\hline umpan & - & 1700 & 46 & 90,38 & 42,64 \\
1 & 4 & 1683 & 1,06 & 5,85 & 4,139 \\
2 & 7 & 3366 & 1,08 & 5,82 & 4,142 \\
\hline
\end{tabular}

Berdasarkan Tabel 4 dapat diketahui bahwa konsentrasi pengotor yang ikut terekstrak berkurang dari konsentrasi awal di umpan ekstraksi. Hal ini menunjukkan bahwa ekstraksi cukup baik untuk mengurangi pengotor yang terekstrak. Meskipun begitu, konsentrasi Th dan $\mathrm{LTJ}_{2} \mathrm{O}_{3}$ dalam fase terekstrak masih lebih tinggi daripada konsentrasi uranium. Hal ini disebabkan oleh konsentrasi Th dan $\mathrm{LTJ}_{2} \mathrm{O}_{3}$ di umpan yang jauh lebih besar daripada konsentrasi uranium di umpan.

Berdasarkan Tabel 4 juga dapat diketahui bahwa konsentrasi uranium dalam organik pada perbandingan $\mathrm{A} / \mathrm{O}=2$ adalah dua kali lipat konsentrasi uranium pada perbandingan $\mathrm{A} / \mathrm{O}=1$, sedangkan pengotor yang terdapat dalam organik pada perbandingan $\mathrm{A} / \mathrm{O}=1$ dan $\mathrm{A} / \mathrm{O}=2$ hampir mendekati sama sehingga ekstraksi dengan $\mathrm{A} / \mathrm{O}=2$ lebih menguntungkan. Selain itu, ekstraksi dengan perbandingan $\mathrm{A} / \mathrm{O}=2$ dapat mengurangi pemakaian organik menjadi setengah dari pemakaian organik pada perbandingan $\mathrm{A} / \mathrm{O}=1$.

Setelah menghitung jumlah stage ekstraksi, dilakukan penentuan jumlah stage stripping. Umpan yang masuk ke proses stripping merupakan organik hasil ekstraksi dengan perbandingan $\mathrm{A} / \mathrm{O}=2$. Konsentrasi $\mathrm{U}$, 
Th, $\mathrm{LTJ}_{2} \mathrm{O}_{3}$, dan $\mathrm{PO}_{4}$ yang masuk ke proses stripping telah ditampilkan dalam Tabel 4. Perhitungan jumlah stage teoretis pada proses stripping dilakukan untuk perbandingan $\mathrm{A} / \mathrm{O}=$ $1,1 / 2$, dan $1 / 5$. Grafik perhitungan jumlah stage stripping pada masing-masing perbandingan $\mathrm{A} / \mathrm{O}$ secara berurutan ditampilkan pada Gambar 9, Gambar 10, dan Gambar 11.

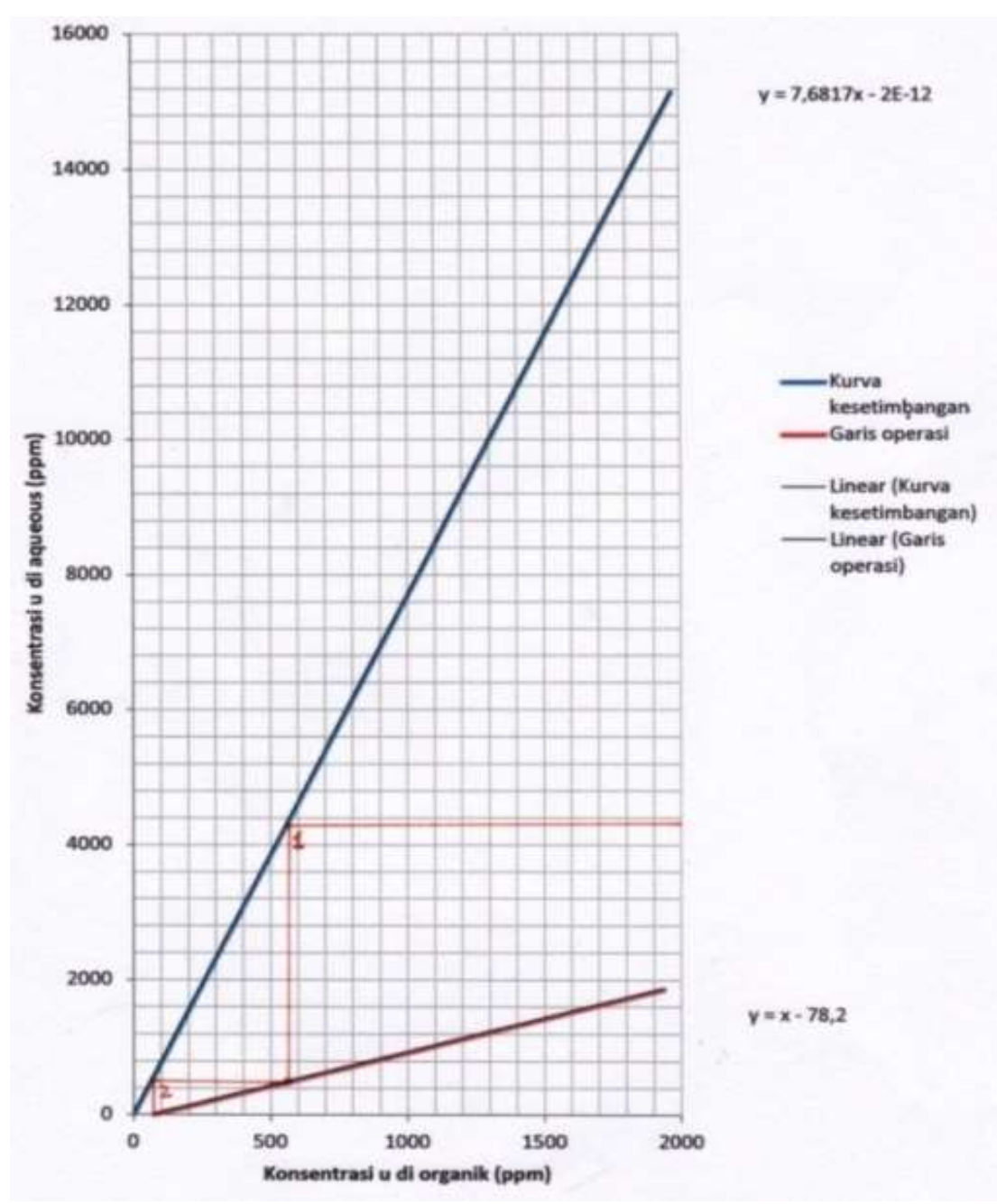

Gambar 9. Kurva Kesetimbangan dan Garis Operasi pada Stripping A/O = 1 


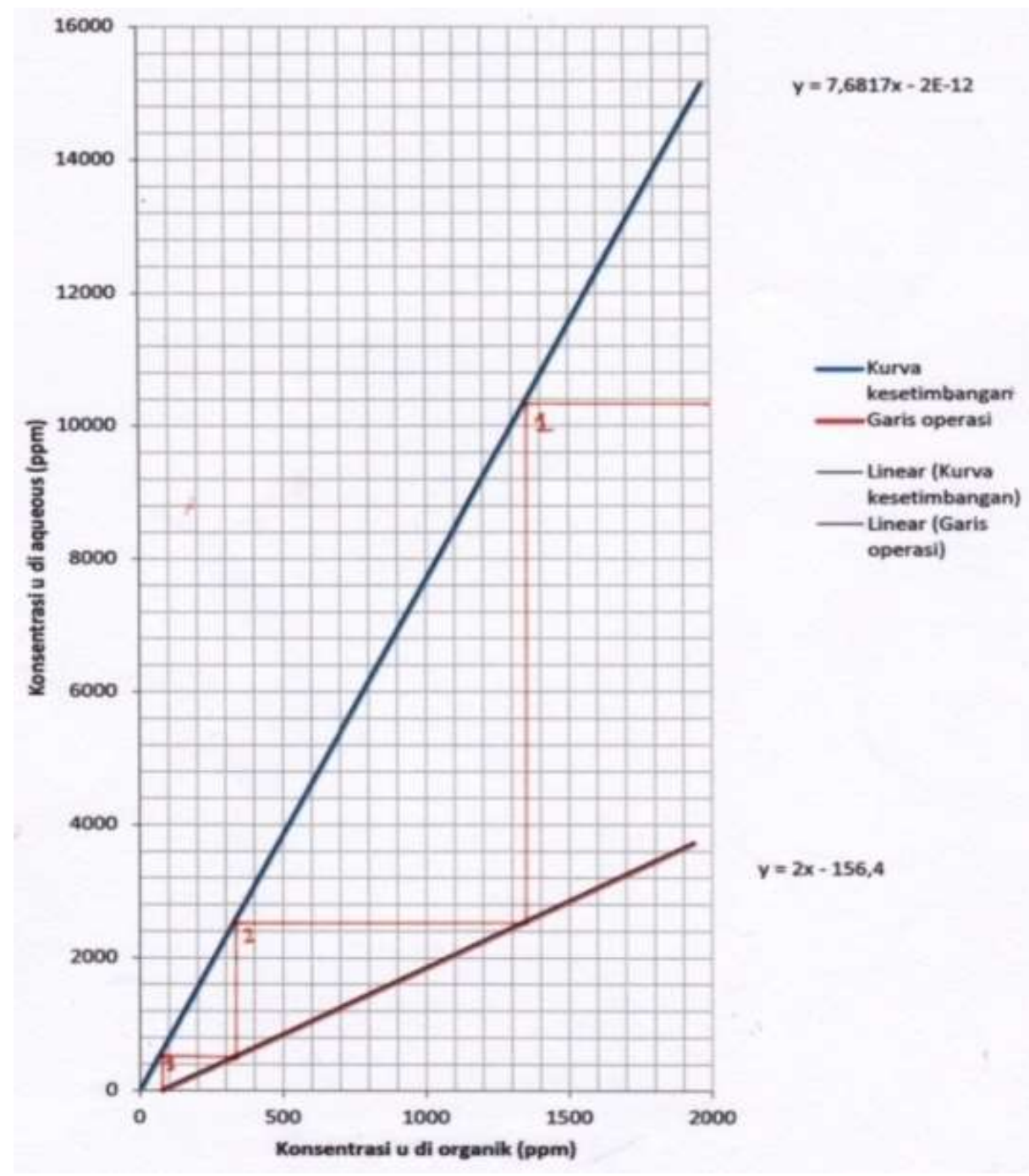

Gambar 10. Kurva Kesetimbangan dan Garis Operasi pada Stripping A/O = 1/2

Berdasarkan Gambar 9, Gambar 10, dan Gambar 11 dapat diketahui bahwa jumlah stage teoretis yang dibutuhkan pada stripping dengan perbandingan $\mathrm{A} / \mathrm{O}=1$ adalah 2 stage, perbandingan $\mathrm{A} / \mathrm{O}=1 / 2$ adalah 3 stage, dan perbandingan $\mathrm{A} / \mathrm{O}=1 / 5$ adalah 6 stage. Pada proses stripping, semakin kecil perbandingan A/O maka konsentrasi uranium dalam larutan stripper akan semakin tinggi sehingga akan memudahkan proses selanjutnya, yaitu proses pengendapan. Pada penentuan jumlah stage ini dipilih stage ekstraksi dengan perbandingan $\mathrm{A} / \mathrm{O}=2$, yaitu 7 stage dan stage stripping dengan perbandingan $\mathrm{A} / \mathrm{O}=1 / 5$, yaitu 6 stage . Pemilihan ini dilakukan berdasarkan konsentrasi uranium yang keluar dari proses stripping pada perbandingan $\mathrm{A} / \mathrm{O}=1 / 5$ menjadi lebih tinggi sehingga akan memudahkan proses pengendapan. 


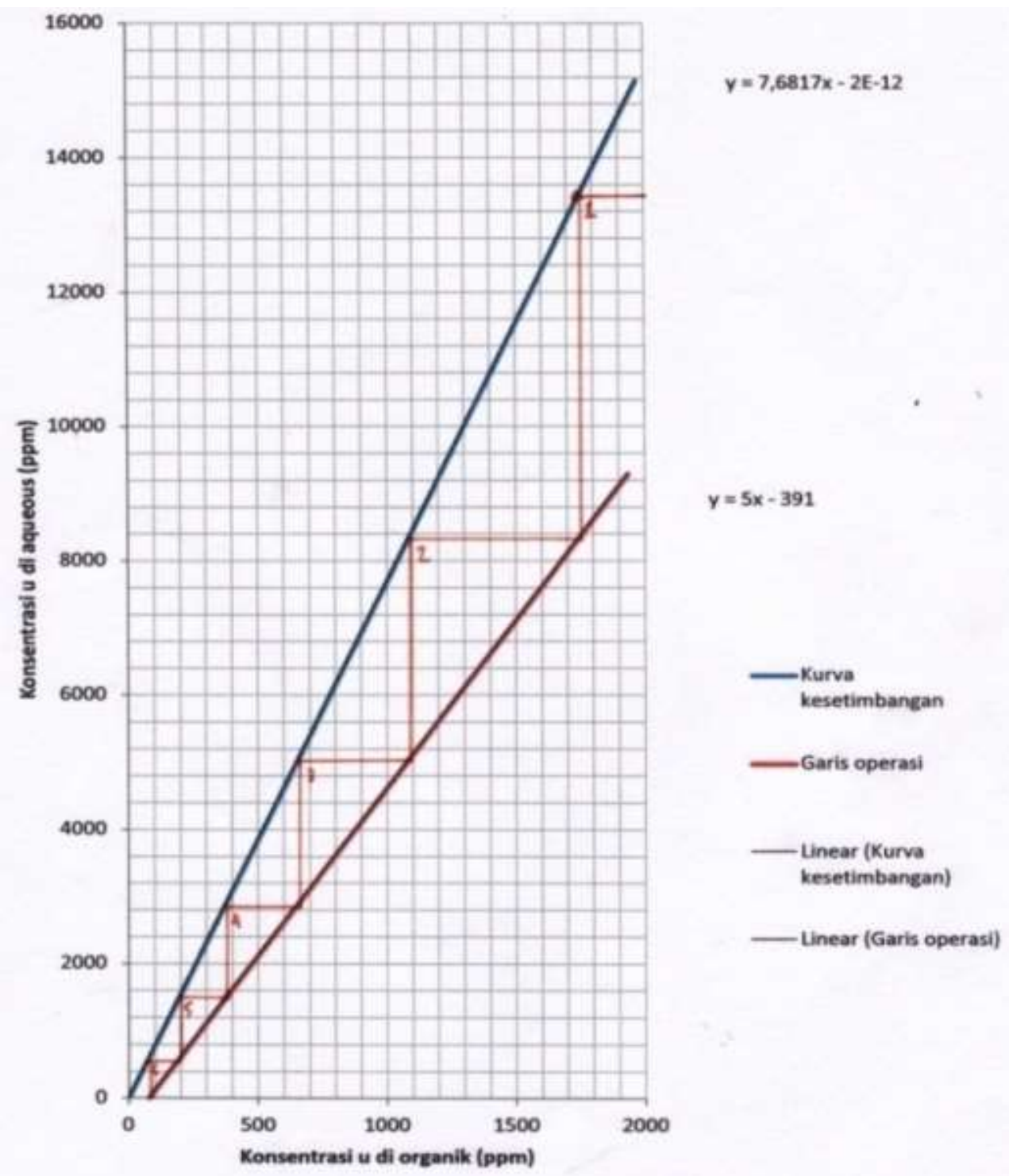

Gambar 11. Kurva Kesetimbangan dan Garis Operasi pada Stripping A/O = 1/5

\section{KESIMPULAN}

Peningkatan jumlah TOA pada perbandingan ekstraktan (TOA:kerosen:isodekanol) menyebabkan peningkatan nilai $\mathrm{Kd}$ uranium dan peningkatan hingga $2 \%$ volume isodekanol juga menyebabkan peningkatan Kd uranium, kemudian turun perlahan. Ekstraksi uranium baik dilakukan pada perbandingan ekstraktan 5:93:2.

1. Peningkatan konsentrasi stripper sampai dengan konsentrasi $\quad \mathrm{H}_{2} \mathrm{SO}_{4} \quad 3 \quad$ M menyebabkan kenaikan nilai $\mathrm{Kd}$ uranium, namun setelah konsentrasi $\mathrm{H}_{2} \mathrm{SO}_{4} 3 \mathrm{M}$ nilai $\mathrm{Kd}$ uranium kembali turun. Stripping torium baik dilakukan pada konsentrasi $\mathrm{H}_{2} \mathrm{SO}_{4} 3 \mathrm{M}$.
2. Nilai koefisien distribusi pada ekstraksi dengan perbandingan ekstraktan (TOA:kerosen:isodekanol $=5: 92: 3$ ) adalah: $\mathrm{U}=3,42 ; \mathrm{Th}=0,02 ; \mathrm{LTJ}_{2} \mathrm{O}_{3}=$ 0,$07 ;$ dan $\mathrm{PO}_{4}=0,10$. Nilai $\mathrm{Kd}$ pada stripping uranium dari ekstraktan tersebut, dengan menggunakan $\mathrm{H}_{2} \mathrm{SO}_{4} 3$ $\mathrm{M}$ adalah $\mathrm{U}=0,13$ dan $\mathrm{Th}=2,21$.

3. Jumlah stage ekstraksi-stripping yang dibutuhkan untuk memperoleh recovery 95\% dengan ekstraksi menggunakan ekstraktan TOA:kerosen:isodekanol= 5:92:3 dan stripper $\mathrm{H}_{2} \mathrm{SO}_{4} 3 \mathrm{M}$ adalah 7 stage ekstraksi pada perbandingan $\mathrm{A} / \mathrm{O}=2$ dan 6 stage stripping pada perbandingan $\mathrm{A} / \mathrm{O}$ $=1 / 5$. 


\section{DAFTAR PUSTAKA}

1. Trinopiawan, K., R. Prassanti, Sumarni, \& R. Pudjianto, 2012. "Pemisahan U dari Th pada Monasit dengan Metode Ekstraksi Pelarut Alamine." dalam: Seminar Geologi Nuklir dan Sumber Daya Tambang PPGN-BATAN. Jakarta.

2. Nuri, H.L., Prayitno, A. Jami, \& M. Pancoko, 2014. "Kebutuhan Desain Awal pada Pilot Plant Pengolahan Monasit Menjadi Thorium Oksida $\left(\mathrm{ThO}_{2}\right)$." dalam: Eksplorium, Vol. 35, No.2, November, hal. 131-141.

3. Cuthbert, F., 1958. Thorium Production Technology. USA: Addison Wesley Publishing Company, Inc.

4. Basset, J., R. Denny, G. Jeffrey \& J. Mendham, 1994. Buku Ajar Vogel Kimia Analisis Kuantitatif Anorganik. Jakarta: Penerbit Buku Kedokteran EGC.

5. Clegg, J. W. \& D.D. Foley, 1958. Uranium Ore Processing. USA: Addisson Wesley Publishing Company, Inc.

6. Benedict, M. \& T.H. Pigford, 1957. Nuclear Chemical Engineering. New York Toronto London: McGraw-Hill Book Company, Inc.

7. Crouse, D. \& K. Brown, 1959. Recovery of Thorium, Uranium, and Rare Earths from Monazite Sulfat Leach Liquors by the Amine Extraction (Amex) Process. Oak Ridge National Laboratory-Union Carbide Nuclear Company.

8. Setyadji, M. \& E. Susiantini, 2002. "Pengaruh Prosen TBP dan Perbandingan Umpan dan Pelarut pada Ekstraksi Uranium-Thorium Proses Thorex." dalam: Prosiding Pertemuan dan Presentasi Ilmiah Penelitian Dasar Ilmu Pengetahuan dan Teknologi Nuklir P3TM-BATAN. Yogyakarta.

9. Morais, C., L. Gomiero, W. Filho \& J. Rangel, 2005. "Uranium Stripping from Tertiary Amine by Sulfuric Acid Solution and Its Precipitation as Uranium Peroxide. in: Minerals Engineering, Vol. 18 Issues 13-14, hal. 1331-1333.

10. Warade, A., R. Gaikwad, R. Sapkal \& V. Sapkal, 2011. "Simulation of Multistage Countercurrent Liquid-Liquid Extraction." in: Leonardo Journal of Science, hal. 79-94.
11. Ritcey, G., 2006. Solvent ExtractionPrinciples and Applications to Process Metallurgy. Canada: G.M. Ritcey \& Associates Incorporated.

12. Coleman, C., K. Brown, J. Moore \& D. Crouse, 1958. Solvent Extraction with Alkyl Amine. International Mining: Focus on Uranium, hal. 1756-1762. 